\title{
ПЕРСПЕКТИВНЫЕ РАЗРАБОТКИ В ПРОИЗВОДСТВЕ ВОЛОКНИСТЫХ ПОЛИМЕРНЫХ СОРБЕНТОВ
}

\begin{abstract}
А. В. Генис, А. В. Кузнецов
АЛЕКСАНДР ВИКТОРОВИЧ ГЕНИС - профессор, доктор техн. наук, заместитель генерального директора по научной работе, АО «Научно-исследовательский институт синтетического волокна с экспериментальным заводом» (АО «ВНИИСВ»). Область научных интересов: теоретические основы формования волокон из растворов и расплавов полимеров, изучение структуры и свойств волокнистых композиционных полимерных материалов, исследования в сфере разработки защитно-фильтрующих материалов для средств индивидуальной защиты органов дыхания и кожи. Маркетинговый анализ в области полимерных материалов и изделия на их основе.
\end{abstract}

АЛЕКСАНДР ВЛАДИМИРОВИЧ КУЗНЕЦОВ - ведущчий научный сотрудник научно-производственного отделения нетканых материалов, АО «Научно-исследовательский институт синтетического волокна с экспериментальным заводом» (АО «ВНИИСВ»). Область научных интересов: композиционные полимерные материалы, прочессы формования волокон из расплавов и растворов полимеров, изучение структуры и свойств волокнистых композиционных полимерных материалов, исследования в сфере разработки сорбциионно-активных композиционных материалов для средств индивидуальной защиты.

170032, г. Тверь, Московское шоссе, д. 157, телефон: +7(4822) 53-76-83,E-mail: npo@vniisv.ru.

Приведена классификащия волокнистых полимерных сорбентов и рассмотрены основные группы данного вида материалов. Представлен перечень мировых компаний и основных стран-производителей волокнистых сорбентов. Рассмотрены особенности технологии аэродинамического формования волокнистых сорбиионно-активных материалов из полимерных растворов. Определены основные структурные параметры влияющие на эксплуатационные характеристики наполненных волокнистых сорбентов, а также методы их регулирования. Проведен анализ преимуществ и недостатков рассмотренных в работе активированных углей.

Ключевые слова: волокнистый сорбент, аэродинамическое формование, реологические свойства, активированный уголь, дисперсный анализ.

\section{PERSPECTIVE DEVELOPMENTS IN THE PRODUCTION OF FIBROUS POLYMERIC SORBENTS}

\author{
A.V. Genis, A. V. Kuznetsov \\ 157, Moskovskoye shosse, Tver, Russia, 170032. Joint-Stock Company «Research Institute of Synthetic Fiber with \\ the Pilot Plant».
}

Classification of fibrous polymeric sorbents is given and the main groups of this kind of materials are considered. The list of world companies and the main countries-producers of fibrous sorbents is presented. The advantages of the technology of aerodynamic spinning of fibrous sorption-active materials from polymer solutions are considered. The main structural parameters influencing the performance characteristics of the 
filled fiber sorbents, as well as the methods of their regulation, are determined. The analysis of advantages and disadvantages of the activated carbons considered in the work is carried out.

Keywords: fibrous sorbent, aerodynamic spinning, rheological properties, activated carbon, disperse analysis.

Волокнистые полимерные сорбенты - одни из наиболее перспективных современных материалов технического назначения. Их характеризуют высокие эластичность, механическая прочность и сорбционная ёмкость. Многообразие физико-механических и адсорбционных свойств волокнистых сорбентов обусловило широкое применение данных материалов в различных отраслях промышленности.

Формирование сорбента в виде волокон позволяет создавать нити, ленты, ткани и нетканые материалы, что открывает широкие возможности аппаратурного оформления процессов очистки воды и воздуха, а также обеспечивает создание более рациональных средств индивидуальной защиты органов дыхания (СИЗОД) и кожи (СИЗК) от химических соединений обладающих высокой токсичностью.

Волокнистые сорбенты получают путем модификации - это один из наиболее простых и эффективных путей регулирования их свойств. Методы модификации полимерных волокон можно разделить на три группы [1]:

- физическая модификация, заключающаяся в активации волокнистого материала, что позволяет существенно повысить сорбционные характеристики волокна;

- химическая модификация, меняющая химическое строение волокнообразующего полимера, для получения волокон с селективными сорбционными свойствами;

- композитная модификация (или метод смешения), когда к основному волокнообразующе- му полимеру (его расплаву или раствору) на стадии формования, либо после него, добавляются те или иные мелкодисперсные компоненты - носители новых свойств.

Всего стоит выделить пять основных групп волокнистых сорбционно-активных полимерных материалов, которые отличаются типом исходного сырья и методом его модификации (рис. 1).

\section{Активированные углеродные волокнистые материалы}

Углеродные волокна (УВ) представляют собой химически очень чистое вещество. Они на $99 \%$ состоят из одного элемента - углерода и до предела насыщены ароматическими кольцами.

Получают УВ термической обработкой химических или природных органических волокон (прекурсоров), таких как целлюлозные, полиакрилонитрильные, пековые. Для придания УВ особых сорбционных свойств проводится модификация либо физическими методами, например, дополнительная термообработка сорбентов, либо за счет химической (электрохимической) обработки, например, окисление азотной кислотой или импрегнирование химически активными веществами [2].

Активированные углеродные волокна (АУВ) это новый класс сорбентов, характеризующийся высокой пористостью и схожий по свойствам с активированными углями. Однако, АУВ не являются просто «волокнистыми активированными углями», они обладают свойствами, которых нет

\section{Методы модификации полимерных волокон}
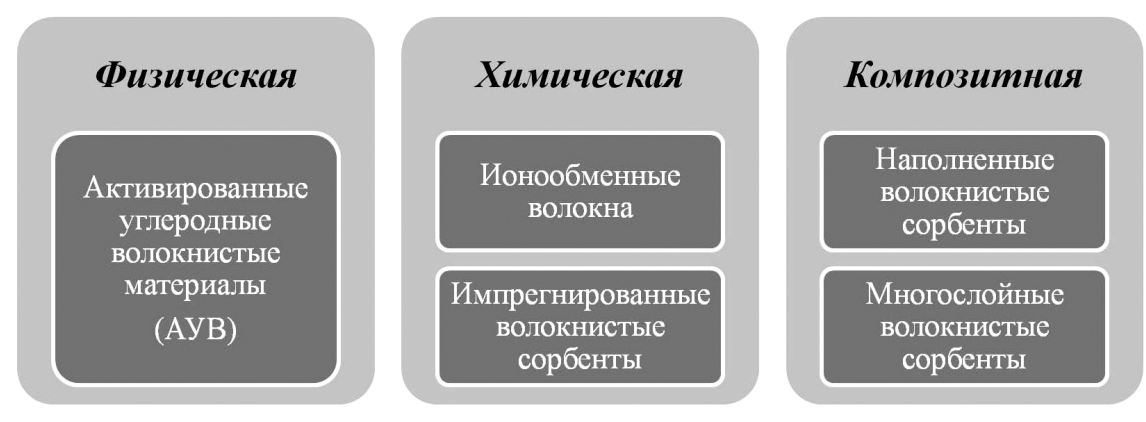

Рис. 1. Основные группы волокнистых полимерных сорбентов и методы их получения 
у традиционных гранулированных и порошкообразных активированных углей. АУВ обладают гораздо более высокой динамикой сорбции по сравнению с активированными углями, а также высокими физико-механическими характеристиками. Это достигается благодаря проведению физической (термообработка) модификации, либо химической (импрегнирование) модификации.

Основные области применения АУВ - это системы воздухоочистки, поглотители запаха, СИЗОД и СИЗК, тонкая очистка газов и жидкостей, фильтры для питьевой воды, химическая промышленность, медицина и т.д.

К недостаткам АУВ следует отнести достаточно сложный и энергоемкий технологический процесс их получения и, как следствие, высокую стоимость по сравнению с активированными углями и другими волокнистыми сорбентами.

Сейчас за рубежом насчитывается около двух десятков производителей активированных углеродных волокнистых материалов из натуральных и синтетических волокон, а также фенольных смол и лигнина. Основными производителями АУВ являются - Calgon Carbon Corporation (США), Unitica (Япония), Evertech Envisafe Ecology, Taiwan Carbon Technology (Тайвань), Anshan Sinocarb Carbon Fibers (Китай) [3].

На территории бывшего Советского Союза активированные углеродные волокнистые материалы выпускаются на предприятиях Союзного государства. Мировым лидером по выпуску УВ из вискозы остается ОАО «Светлогорск Химволокно» (Беларусь). В России АУВ производят ОАО «ЭНПО «Неорганика» и ООО «НПЦ «УВИКОМ».

\section{Ионообменные волокнистые материалы}

Ионообменные волокна обладают высокоразвитой поверхностью и лучшими кинетическими характеристиками по сравнению с зернистыми ионитами (высокая скорость обмена, большая доступность ионогенных групп для обмениваемых ионов, в том числе крупных органических ионов) [4].

Для получения волокнистых ионитов применяются две группы методов:

- химическая модификация готовых волокон путем полимераналогичных превращений и привитой сополимеризации (или сополиконденсации);

- формование волокон из смесей неволокнообразующих полимеров с ионогенными группами и волокнообразующих полимеров без функциональных групп.

По своей химической природе ионообменные волокна разделяются на катиониты (способные к обмену катионов), аниониты (способные к обме- ну анионов), амфолиты (содержащие одновременно кислотные и основные группы).

Производителями в России и Белоруссии налажен выпуск широкого ассортимента ионообменных волокнистых материалов, марок ВИОН, ПАНИОН, ФИБАН, МИОН, которые в настоящий момент используются при производстве конкурентоспособных изделий, таких как, пылегазозащитные респираторы, защитные костюмы, фильтры для очистки воды и воздуха, автомобильные фильтры, промышленные вентиляционные системы (таблица 1).

За рубежом ионообменным волокнистым материалам уделяется мало внимания, за исключением Китая, где выпускаются материалы марки CATALON аналогичные по свойствам ионообменным волокнам ПАНИОН, производимых в Белоруссии. Предпочтение отдается другим волокнистым сорбентам, преимущественно АУВ.

\section{Импрегнированные волокнистые сорбенты}

С целью придания волокнистым полимерным материалам селективных сорбционных свойств, либо для повышения сорбционной активности и защитного действия волокнистых сорбентов, их подвергают химической модификации, путем импрегнирования волокнистого материала различными солями и катализаторами.

Для получения импрегнированных волокнистых сорбентов, обеспечивающих защиту от различных классов аварийно-химически опасных веществ (АХОВ), используют соответствующие соединения. Импрегнирование, как правило, проводится методом пропитки волокнистого материала (основы) с дальнейшим упариванием раствоpa. В качестве волокнистой основы используются тканые и нетканые материалы из химических или природных органических волокон (хлопчатобумажная ткань, полиакрилонитрил, полиэфир, полипропилен), а также волокнистые сорбенты (АУВ и ионообменные волокна) $[5,6]$.

Для защиты от АХОВ класса В (хлор, неорганические газы и пары) используют пропитку растворами $\mathrm{K}_{2} \mathrm{CO}_{3}$; класса Е (диоксид серы, кислые газы) - $\mathrm{KMnO}_{4}$ и $\mathrm{KI}$; класса $\mathrm{K}$ (аммиак и его производные) - растворами $\mathrm{NiCl}_{2}$ и $\mathrm{CuSO}_{4}$.

В России импрегнированные волокнистые сорбенты производит АО «КазХимНИИ» в виде химзащитных тканей с высокими значениями времени защитного действия (ВЗД) от капель жидких ядохимикатов, которые применяются для изготовления специальной одежды и респираторов-капюшонов, предназначенных для защиты кожных покровов и органов дыхания человека от воздействия паров аммиака, хлора, хлористого водорода, 
Таблица 1

Крупнейшие производители ионообменных волокнистых материалов, выпускаемых в Союзном государстве

\begin{tabular}{|c|c|c|c|c|}
\hline Производитель & Страна & $\begin{array}{c}\text { Марка } \\
\text { материала }\end{array}$ & $\begin{array}{c}\text { Тип } \\
\text { материала }\end{array}$ & Области применения \\
\hline $\begin{array}{l}\text { ООО } \\
\text { «ИМТ-Фильтр» }\end{array}$ & Беларусь & ПАНИОН 220 & $\begin{array}{c}\text { Полиамфолит } \\
\text { с преимуществен- } \\
\text { ным содержанием } \\
\text { аминогрупп }\end{array}$ & $\begin{array}{l}\text { Очистка воздуха от веществ кислой } \\
\text { природы }\left(\mathrm{SO}_{2}, \mathrm{SO}_{3}, \mathrm{HF}, \mathrm{HCl}, \mathrm{H}_{2} \mathrm{SO}_{4},\right. \\
\left.\mathrm{N}_{\mathrm{x}} \mathrm{O}_{y}, \mathrm{CrO}_{3}\right) \text {. Изготовление СИЗК } \\
\text { и СИЗОД }\end{array}$ \\
\hline \multirow{2}{*}{$\begin{array}{l}\text { Институт } \\
\text { физико- } \\
\text { органической } \\
\text { химии }\end{array}$} & \multirow{2}{*}{ Беларусь } & ФИБАН Х-1 & Хелатный ионит & $\begin{array}{l}\text { Очистка воздуха от газообразных } \\
\text { и аэрозольных примесей основной } \\
\text { природы. Изготовление СИЗК и СИЗОД }\end{array}$ \\
\hline & & ФИБАН К-4 & $\begin{array}{l}\text { Слабокислотный } \\
\text { катионит }\end{array}$ & $\begin{array}{l}\text { Очистка вентвыбросов промышленных } \\
\text { предприятий от } \mathrm{NH}_{3} \text {, аминов, аэрозолей } \\
\text { щелочей. Изготовление СИЗОД }\end{array}$ \\
\hline $\begin{array}{l}\text { ООО } \\
\text { «Иматек и К» }\end{array}$ & Беларусь & МИОН К-5 & $\begin{array}{c}\text { Слабокислотный } \\
\text { катионит }\end{array}$ & $\begin{array}{l}\text { Применяется в вентиляционных } \\
\text { фильтрах для очистки воздуха от } \mathrm{NH}_{3} \text {, } \\
\text { органических аминов. Изготовление } \\
\text { СИЗОД }\end{array}$ \\
\hline \multirow{2}{*}{$\begin{array}{l}\text { ООО } \\
\text { «ЛИРСОТ» }\end{array}$} & \multirow{2}{*}{ Россия } & ВИОН АН-3 & $\begin{array}{c}\text { Полиамфолитный } \\
\text { катионит }\end{array}$ & $\begin{array}{l}\text { Очистки газовоздушной и жидкой сред } \\
\text { от } \mathrm{SO}_{2}, \mathrm{HF}, \mathrm{HCI}, \mathrm{H}_{2} \mathrm{~S}\end{array}$ \\
\hline & & ВИОН КН-1 & $\begin{array}{l}\text { Слабокислый } \\
\text { катионит }\end{array}$ & $\begin{array}{l}\text { Очистка газовоздушной среды от } \mathrm{SO}_{2} \text {, } \\
\mathrm{SO}_{3}, \mathrm{NH}_{3}\end{array}$ \\
\hline
\end{tabular}

Характеристики импрегнированных волокнистых сорбентов выпускаемых в АО «КазХимНИИ»

\begin{tabular}{|c|c|c|c|c|}
\hline \multirow{2}{*}{$\begin{array}{c}\text { Марка } \\
\text { материала }\end{array}$} & \multirow{2}{*}{ Способ получения } & \multirow{2}{*}{ Области применения } & \multicolumn{2}{|c|}{$\begin{array}{c}\text { ВЗД, мин, } \\
\text { не менее }\end{array}$} \\
\hline & & & $\begin{array}{c}\text { от капель } \\
\text { и паров } \\
\text { аммиака }\end{array}$ & $\begin{array}{c}\text { от капель } \\
\text { ядохимикатов }\end{array}$ \\
\hline ТЛ-3 & $\begin{array}{l}\text { Перед пропиткой ткань-основа } \\
\text { обрабатывается кремнезолем, } \\
\text { а пропитка осуществляется рас- } \\
\text { творами ферроцианида калия } \\
\text { и соли меди, с последующей } \\
\text { отмывкой ткани от водораство- } \\
\text { римых соединений }\end{array}$ & $\begin{array}{l}\text { Изготовление комплекта } \\
\text { фильтрующей защитной } \\
\text { одежды (ФЗО) - ФЗО-МП-2, } \\
\text { предназначенной для защиты } \\
\text { кожных покровов человека от } \\
\text { воздействия паров аммиака, } \\
\text { гидразина и его производных }\end{array}$ & 20 & 360 \\
\hline ФЦМ-П & $\begin{array}{l}\text { На хлопчатобумажную ткань } \\
\text { наносится сорбент ферроцианид } \\
\text { меди путем последовательной } \\
\text { обработки ткани водными рас- } \\
\text { творами солей меди, с последу- } \\
\text { ющей отмывкой от водораство- } \\
\text { римых соединений }\end{array}$ & $\begin{array}{l}\text { Изготовление комплекта } \\
\text { фильтрующей защитной } \\
\text { одежды (ФЗО) - ФЗО-МП, } \\
\text { ФЗО-МП-А, ФЗО-Р, предна- } \\
\text { значенной для защиты от хи- } \\
\text { мических веществ длительно- } \\
\text { го использования }\end{array}$ & 20 & - \\
\hline УЗМ-ПВС & $\begin{array}{l}\text { Пропитка хлопчатобумаж- } \\
\text { ной ткани-основы раствором, } \\
\text { включающим активированный } \\
\text { уголь, кремнезоль и поливини- } \\
\text { ловый спирт }\end{array}$ & $\begin{array}{l}\text { Изготовление респираторов- } \\
\text { капюшонов и других средств } \\
\text { индивидуальной защиты ор- } \\
\text { ганов дыхания человека }\end{array}$ & 20 & - \\
\hline
\end{tabular}


гидразина, различных аминов. Технология получения предусматривает пропитку хлопчатобумажной ткани-основы раствором, включающим активированный уголь, кремнезоль, ферроцианид меди и поливиниловый спирт (Таблица 2).

\section{Наполненные волокнистые материалы}

Для придания волокнистым полимерным материалам сорбционных свойств широко применяется способ композитной модификации, который заключается во введении в волокнистую основу гранулированного или мелкодисперсного сорбционно-активного наполнителя. Основных способов композитной модификации можно выделить три:

Способ 1. Наполнитель вводится в уже сформованный волокнистый холст;

Способ 2. Введение наполнителя непосредственно во время формования;

Способ 3. Введение наполнителя в раствор полимера на стадии подготовки к формованию волокнистого материала.

Самым распространенным за рубежом методом получения наполненных волокнистых сорбционно-активных материалов является введение мелкодисперсного (пылевидного) сорбента в уже готовый нетканый холст - волокнистую основу (способ 1), путем пропускания через неё пылевоздушной смеси. Данная технология была разработана еще в начале 60 -х годов и в течении многих лет совершенствовалась, однако наполненные материалы получаемые таким способом имеют ряд серьезных недостатков.

Во-первых, данный способ наполнения не дает возможности получить достаточно протяженный слой пылевидного сорбента в объеме сорбционно-фильтрующего материала и ограничивает количество вносимого в него сорбента, не позволяя получить поверхностную плотность сорбента (масса сорбента, приходящаяся на единицу площади сорбционно-фильтрующего материала) более $40-50 \Gamma / \mathrm{M}^{2}$.

Во-вторых, частицы пылевидного сорбента осаждаются на волокнах и располагаются в его слое так, что их концентрация убывает по экспоненциальной зависимости по мере увеличения глубины их проникновения в слой. Большинство частиц пылевидного сорбента оказываются сконцентрированными в поверхностном слое волокнистого материала. В этом случае относительное отклонение от номинального значения поверхностной плотности сорбционно-фильтрующего материала может достигать 30-50 \%, что приводит к снижению времени защитного действия изделий на его основе.
B-третьих, частицы пылевидного сорбента, которые недостаточно глубоко проникли в слой сорбционно-фильтрующего материала и поэтому недостаточно прочно закрепились на его волокнах, в процессе изготовления изделий, транспортировки и хранения материала высыпаются, что приводит к уменьшению поверхностной плотности. Все это ограничивает сорбционную емкость и, следовательно, время защитного действия наполненного волокнистого материала, получаемого с использованием данного способа.

Эти недостатки частично устраняются путем электризации частиц пылевидного сорбента, закручиванием пылевоздушной смеси в вихревом потоке при давлении 0,10-0,15 МПа, применения знакопеременной пульсирующей вибрации с частотой 700-1000 импульсов в минуту, пропиткой волокнистой основы клеем, термофиксации и т.д.

К крупнейшим производителям наполненных волокнистых материалов, путем введения мелкодисперсного (пылевидного) сорбента в уже готовый нетканый холст, можно отнести такие фирмы, как Permatron Corporation (США), Mann+Hummel (Германия), Evertech Envisafe Ecology (Тайвань), Guangzhou Sun Holy Wind Air Cleaning Products (Китай). В качестве волокнистой основы, как правило, используется полипропиленовые или полиэфирные нетканые материалы, а в качестве сорбента - мелкодисперсные активированные угли (кокосовые и бамбуковые).

Проблемы с малой поверхностной плотностью материала и неравномерностью распределения наполнителя могут быть решены при введении наполнителя непосредственно в процессе расплавного аэродинамического формования (способ 2), который заключается в одноосном растяжении струи расплава полимера потоком сжатого воздуха.

Однако полученный таким способом волокнистый материал будет обладать низкими физико-механическими характеристиками. Кроме того возможно высыпание сорбента из-за непрочного закрепления внутри полимерной матрицы, что значительно ограничивает область применения таких материалов [7].

К подобным материалам относятся наполненные нетканые волокнистые сорбенты марки Aerolace, выпускаемые компанией K.J. Filtration Technologies (Тайвань). Данные материалы производятся путем введения сорбционно-активного наполнителя непосредственно во время аэродинамического формования расплава полипропилена. Для повышения физико-механических свойств материал армируют дополнительными слоями нетканого материала. В качестве сорбционно-активных наполнителей применяются активированные 
угли, активированные оксиды алюминия, ионообменные смолы.

В АО «ВНИИСВ» (Россия) была разработана технология аэродинамического формования волокнистых сорбционно-активных материалов из полимерных растворов, содержащих различные наполнители (способ 3). Процесс получения наполненного волокнистого материала сводится к приготовлению прядильной композиции, представляющей собой суспензию мелкодисперсного наполнителя в растворе волокнообразующего полимера, формованию из этой композиции холста и его отделки, включающей промывку и сушку [8, 9].

По сравнению с волокнистыми сорбентами получаемыми по способу 1 и 2 данная технология дает возможность получать материалы со значительной поверхностной плотностью (до 300 г/ $\mathrm{M}^{2}$ ) и высоким содержанием наполнителя (до 70 \% по массе), равномерно распределенного по всему объему материала. Частицы сорбционно-активного наполнителя оказываются прочно закреплены внутри полимерной матрицы, вследствие чего наполнитель не высыпается и не вымывается в процессе эксплуатации (рис. 2).

\section{Обоснование выбора сырья для приготовления прядильных композиций}

В качестве волокнообразующего полимера был выбран полиакрилонитрил (ПАН), синтезированный методом суспензионной полимеризации. Преимущество ПАН перед другими волокнообразующими полимерами заключается в том, что в процессе аэродинамического формования наполненного раствора ПАН образуется высокопористая по- лимерная матрица, способствующая быстрой диффузии газов (паров) одного или нескольких АХОВ к частицам сорбционно-активного наполнителя.

Проанализировав широкий спектр материалов применяемых для производства СИЗ от АХОВ различных классов, установлено, что для создания массовых, дешевых и эффективных СИЗ наиболее приемлемыми сорбционно-активными наполнителями являются углеродные сорбенты (активированные угли) [10].

Марки активированных углей выбирались по типу сырья, из которого они изготовлены (каменный или древесный уголь, торф, скорлупа кокосового ореха), по способу активации (термохимическая, паровая, химическая), по назначению (газовые, рекуперационные, осветляющие и угли-носители катализаторов-хемосорбентов), форме выпуска (порошковый, гранулированный, экструдированный), а также по суммарной площади поверхности, которая в значительной степени определяет его сорбционную эффективность (таблица 3).

Выбор оптимального растворителя для приготовления прядильной композиции крайне важен, так как с растворителем обладающим лучшими термодинамическими качествами будет получен раствор с меньшей вязкостью, при одной и той же концентрации полимера $\left(C_{\text {ПлН }}\right)$, что снизит затраты энергии на всех стадиях, связанных с приготовлением суспензии, транспортировкой и формованием нетканого холста.

Для сравнения в таблице 4 приведены значения логарифмов вязкости растворов ПАН с наиболее распространенными органическими и неорганическими растворителями, такими как диметилформамид (ДМФ), диметилсульфоксид (ДМСО),

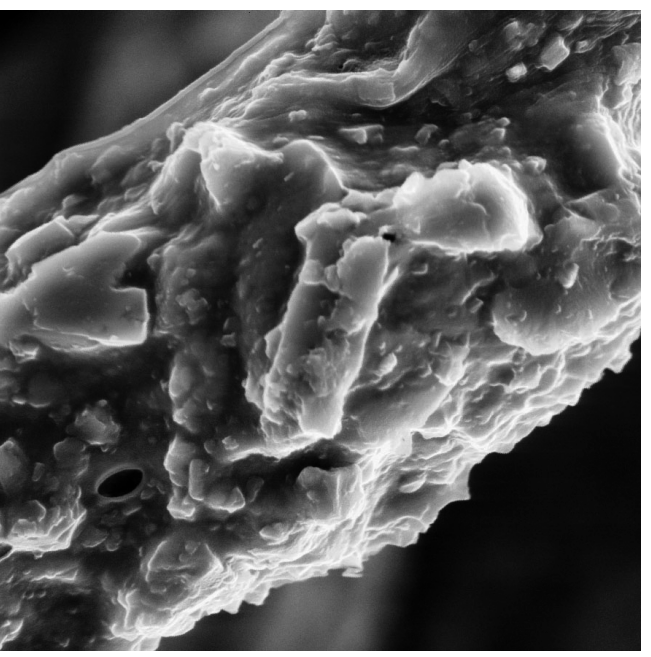

б

Рис. 2. Электронные микрофотографии волокнистого сорбционно-активного материала марки ВСАМ, выпускаемого в АО «ВНИИСВ» по технологии растворного аэродинамического формования: а - увеличение 60x; б - увеличение 2700x 
Технические характеристики различных марок активированных углей

\begin{tabular}{|c|c|c|c|c|}
\hline Марка угля & 208CP & БАУ-МФ & СКТ-6 & $A \Gamma-5$ \\
\hline $\begin{array}{l}\text { Способ } \\
\text { получения }\end{array}$ & $\begin{array}{c}\text { Из скорлупы } \\
\text { кокосового ореха }\end{array}$ & $\begin{array}{c}\text { Из дробленого дре- } \\
\text { весного угля-сырца, } \\
\text { методом парогазо- } \\
\text { вой конденсации }\end{array}$ & $\begin{array}{c}\text { Из торфа, методом } \\
\text { химической акти- } \\
\text { вации }\end{array}$ & $\begin{array}{c}\text { Из каменноугольной } \\
\text { пыли и связующего, ме- } \\
\text { тодом парогазовой кон- } \\
\text { денсации }\end{array}$ \\
\hline $\begin{array}{l}\text { Форма } \\
\text { выпуска }\end{array}$ & Порошковый & $\begin{array}{c}\text { Гранулированный } \\
\text { (дробленый) }\end{array}$ & $\begin{array}{c}\text { Экструдированный } \\
\text { (цилиндрические } \\
\text { гранулы) }\end{array}$ & $\begin{array}{l}\text { Экструдированный (ци- } \\
\text { линдрические гранулы) }\end{array}$ \\
\hline Назначение & $\begin{array}{c}\text { Очистка стоков } \\
\text { и вентиляционных } \\
\text { выбросов }\end{array}$ & $\begin{array}{c}\text { Для локальной } \\
\text { очистки питьевой } \\
\text { воды }\end{array}$ & $\begin{array}{c}\text { Для адсорбции па- } \\
\text { ров органических } \\
\text { веществ }\end{array}$ & $\begin{array}{c}\text { Основа для химических } \\
\text { поглотителей для проти- } \\
\text { вогазовой техники }\end{array}$ \\
\hline $\begin{array}{l}\text { Площадь } \\
\text { поверхности, м²/Г }\end{array}$ & $1150-1350$ & $600-900$ & $1200-1500$ & $800-1000$ \\
\hline
\end{tabular}

Таблий 4

Влияние природы растворителя на вязкость концентрированных растворов ПАН

\begin{tabular}{|c|c|c|c|c|}
\hline \multirow{2}{*}{$C_{\text {IIAH }}, \%$ (масс.) } & \multicolumn{4}{|c|}{$\lg \eta_{p}$} \\
\hline & ДМФ & ДМсо & NaSCN & $\mathrm{ZnCl}_{2}$ \\
\hline 10 & 0,67 & 0,85 & 1,41 & 1,80 \\
\hline 11 & 0,91 & 1,05 & 2,12 & 2,76 \\
\hline 12 & 1,10 & 1,35 & 2,75 & - \\
\hline 13,5 & 1,39 & 1,77 & - & - \\
\hline
\end{tabular}

$51 \%$ водный раствор роданида натрия и $60 \%$ водный раствор хлорида цинка.

Полученные нами экспериментальные данные (таблица 2) позволили сделать вывод, что для приготовления наполненных прядильных растворов ПАН гораздо более предпочтительными выглядят органические растворители, а лучшим по качеству, относительно наименьшей вязкости $\left(\eta_{p}\right)$, следует считать ДМФ.

\section{Реологические свойства прядильных композиций}

Другим важным технологическим фактором, определяющим эффективность переработки суспензии, состоящей из волокнообразующего полимера, растворителя и мелкодисперсного напол-

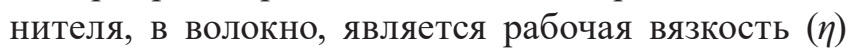
наполненной прядильной системы, которая зависит от свойств полимерной среды, концентрации и размеров частиц наполнителя. Необходимо учитывать, что если в растворе формируется структура, образованная частицами наполнителя, то вязкость наполненного раствора в значительной мере будет зависеть от такой структуры.
Таким образом, особенности реологических свойств наполненных полимерных растворов будут определяться сочетанием характеристик дисперсионной среды и механических свойств структуры, образованной в результате взаимодействия частиц наполнителя [11].

Для оценки влияния природы сорбционно-активных наполнителей на реологические свойства прядильных полимерных композиций была приготовлена серия наполненных полимерных растворов с различной концентрацией ПАН в ДМФ и объемным содержанием наполнителей.

Если суспензия составлена изначально из сухого порошка, массовое содержание которого в суспензии и плотность, как и плотность дисперсионной среды известны, то объемное содержание твердой фазы $(\varphi)$, соответствующее составу исходных компонентов суспензии равно:

$$
\varphi=\varphi_{\grave{I}} \rho_{\grave{I}}^{-1}\left[\varphi_{\grave{I}} \rho_{\grave{I}}^{-1}+\left(1-\varphi_{\grave{I}}\right) \rho_{\tilde{n}}^{-1}\right]^{-1}
$$

где $\varphi_{м}-$ массовая доля наполнителя в суспензии;

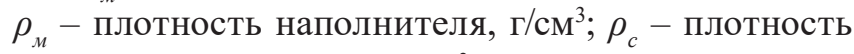

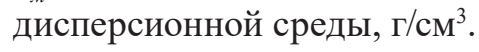


С помощью ротационного вискозиметра погружного типа «Полимер РПЭ-1М.2», с воспринимающими элементами типа «цилиндр-цилиндр» с разными градиентами скорости сдвига, у приготовленных суспензий определялась динамическая вязкость. Из экспериментальных данных (таблица 5) видно, насколько сильное влияние оказывает объемное содержание различных типов сорбционно-активных наполнителей, введенных в раствор ПАН, на вязкость прядильной композиции.

Для пояснения полученных результатов воспользуемся современной реологической теорией течения суспензий, в которой наполненные полимерные системы представлены как двухфазные, а дисперсионная среда фактически и определяет их вязкость. Разумеется, только та её часть, которая не заключена внутри агрегатов частиц, не присоединена каким-либо образом к частицам и является по этому признаку «свободной». В этом случае суммарная толщина и вязкость прослоек «свободной» дисперсионной среды обуславливает вязкость двухфазных сред [12].

Согласно изложенной теории факторы, определяющие вязкость суспензий, такие как взаимодействие частиц, образование и разрушение их агрегатных структур, степень наполнения суспензии и дисперсность твердой фазы, непосредственно влияют прежде всего на толщину прослоек свободной части дисперсионной среды, а они уже - на вязкость суспензии.

Из уравнений, предложенных для описания вязкости суспензий [11 - 13], наиболее точные результаты дает уравнение (2), которое показывает, что относительная вязкость $\left(\eta / \eta_{p}\right)$ полимерных растворов наполненных частицами различной дисперсности и формы зависит только от величины $\varphi_{m}$, а происходящая агломерация частиц наполнителя в растворе полимера приводит к уменьшению $\varphi_{m}$ и росту вязкости ( $\eta$ ) (таблица 5). Наиболее интенсивная агломерация наблюдается в суспензии содержащей уголь $208 \mathrm{CP}$, сопровождающаяся бо- лее значительным увеличением вязкости по сравнению с другими активированными углями.

$$
\eta / \eta_{\delta}=\left[1-\left(\varphi / \varphi_{m}\right)\right]^{-2,5}
$$

где $\varphi$ - объемная доля наполнителя в суспензии; $\varphi_{m}-$ степень наполнения при плотной упаковке частиц; $\eta$ - вязкость наполненного раствора полимера, измененная под влиянием ограничивающих молекулярную подвижность частиц наполнителя, Па:с; $\eta_{p}-$ вязкость раствора ПАН в ДМФ (вязкость дисперсионной среды), Па·с; $\eta / \eta_{p}-$ относительная вязкость наполненного раствора полимера.

Необходимо отметить, что для упрощения выкладок в расчетах было принято, что форма всех частиц твердой фазы сферическая. Данное приближение облегчает математическое описание, лучше отражая сущность теории течения суспензий.

Для рассматриваемых марок наполнителей (таблица 5) при высоком объемном содержании частиц в прядильной композиции $(\varphi>0,35)$ теоретическое значение $\eta$ в уравнении (2) в общем случае в полной мере не соответствуют экспериментальным данным, поскольку течение суспензии при этом переходит в неньютоновское и её вязкость становится функцией градиента скорости сдвига.

Вязкость высококонцентрированных прядильных композиций уменьшается с ростом градиента скорости сдвига, то есть можно утверждать, что растворы ПАН в ДМФ с высоким объемным содержанием активированных углей обладают псевдопластическими свойствами.

В частности при течении раствора полимера с концентрацией ПАН 13,5 \%, наполненного активированным углем $208 \mathrm{CP}$, уже при $\varphi=0,25$ переходит в неньютоновское, а при $\varphi=0,45$ суспензия практически не течет и экспериментально определить её вязкость невозможно.

При $\varphi>0,45$ происходит полное захватывание дисперсионной среды в единую систему - образуется коллоидный гель, в ячейках которого

Таблица 5

Реологические параметры прядильных композиций $\left(C_{\text {пAH }}=13,5\right.$ \% масс.) с различным объемным содержанием наполнителей, вычисленные по уравнению (2) и полученные экспериментально

\begin{tabular}{|c|c|c|c|c|c|c|c|c|c|c|c|c|}
\hline $\begin{array}{c}\text { Марка } \\
\text { угля }\end{array}$ & \multicolumn{3}{|c|}{ 208CP } & \multicolumn{3}{|c|}{ БАУ-МФ } & \multicolumn{3}{|c|}{ СКТ-6 } & \multicolumn{3}{|c|}{ AГ-5 } \\
\hline$\varphi_{m}$ & \multicolumn{3}{|c|}{0,59} & \multicolumn{3}{|c|}{0,66} & \multicolumn{3}{|c|}{0,69} & \multicolumn{3}{|c|}{0,83} \\
\hline$\varphi$ & 0,05 & 0,25 & 0,35 & 0,05 & 0,25 & 0,35 & 0,05 & 0,25 & 0,35 & 0,05 & 0,25 & 0,35 \\
\hline \multirow{2}{*}{ Расч. } & \multicolumn{3}{|c|}{$\eta, \Pi а \cdot c$} & \multicolumn{3}{|c|}{$\eta, \Pi а \cdot c$} & \multicolumn{3}{|c|}{$\eta$, Па с } & \multicolumn{3}{|c|}{$\eta$, Па с } \\
\hline & 29,6 & 95,0 & 227,0 & 29,8 & 78,8 & 158,5 & 28,9 & 73,8 & 140,6 & 28,0 & 58,7 & 94,2 \\
\hline Эксп. & 28,8 & 92,5 & 245,5 & 28,6 & 79,3 & 175,6 & 28,1 & 69,8 & 150,1 & 27,7 & 58,9 & 98,5 \\
\hline
\end{tabular}


достаточно прочно удерживается весь объем ПАН растворенного в ДМФ, в результате чего у суспензии перестает наблюдаться текучесть.

Вязкость прядильной композиции, наполненной углём марки АГ-5, значительно меньше (таблица 3), чем у 208СР и не зависит от скорости сдвига вплоть до $\varphi=0,45$. Реологические свойства активированных углей БАУ-МФ и СКТ-6 практически идентичны.

Важным технологическим параметром, определяющим возможность получения наполненного нетканого материала с требуемыми свойствами, является стабильность реологических свойств прядильной композиции. Если суспензия обладает низкой стабильностью, то в процессе формования нетканого наполненного материала реологические свойства прядильной композиции будут значительно изменяться и заметно влиять на эксплуатационные характеристики готового материала, что является крайне нежелательным.

Количественно стабильность прядильных композиций с различными наполнителями можно оценить по скорости изменения вязкости, которая определяется количеством адсорбированной активированным углем дисперсионной среды. Чем меньше время, в течении которого вязкость суспензии перестает расти и становится постоянной, тем выше стабильность приготовленной прядильной композиции.

При использовании в качестве наполнителей активированных углей 208СР и СКТ-6 вязкость прядильных композиций увеличивается не более чем на $20 \%$ от начальной и перестает меняться уже менее чем через сутки после их приготовления. При использовании активированных углей БАУ-МФ и АГ-5 вязкость увеличивается в 2-3 раза, а рост вязкости прядильных суспензий содержащих эти угли продолжается в течении 23-24 суток с момента их приготовления.

Таким образом, по технологическому показателю стабильности прядильные композиции на основе активированных углей 208СР и СКТ-6 являются предпочтительными, однако с учетом высокой цены угля марки СКТ-6, вдвое превышающей аналогичный показатель угля $208 \mathrm{CP}$, окончательный выбор сделан в пользу последнего.

Согласно реологической теории течения суспензий одним из факторов, определяющих вязкость, является дисперсность твердой фазы. Данный фактор влияет на содержание наполнителя, соответствующее предельно плотной упаковке частиц $\left(\varphi_{m}\right)$, на его сорбционную активность, а также на вероятность получения равномерного волокнистого холста, состоящего из тонких наполненных элементарных волокон.
Из полученных экспериментальных данных было установлено, что увеличение доли мелкодисперсной фракции, независимо от типа наполнителя, повышает вязкость прядильной композиции, сразу после приготовления, всего на 10 - 12 Па·с, за счет более плотной упаковке частиц дисперсионной фазы.

\section{Аэродинамическое формование наполненных волокнистых материалов}

В процессе проведенных исследований установлено, что на эффективность переработки прядильной композиции влияет рабочая вязкость наполненной прядильной системы, которая зависит от свойств полимерной среды, природы растворителя и наполнителя, дисперсности последнего и его объемной доли в суспензии. В целом это означает, что струи прядильных композиций, имеющих более высокую вязкость, требуют большей скорости потоков сжатого воздуха для реализации устойчивого формования.

С учетом высказанных предположений было произведено формование прядильных композиций, содержащих в качестве наполнителей активированные угли различной природы.

По мере увеличения скорости воздушного потока аэродинамическое растяжение струи осуществляется в двух характерных скоростных зонах. На рисунке 3 показаны определенные экспериментально границы зон формуемости эквивязких (с ньютоновской вязкостью 30-33 Па·с) прядильных композиций, с различными сорбционноактивными наполнителями и весовой долей тонкой фракции (размер частиц меньше 50 мкм) 70$80 \%$. Сами зоны могут быть охарактеризованы следующим образом:

- зона неформуемости (кратность растяжения менее 2000), в которой струя существует в состоянии ярко выраженных пульсаций диаметра или распадается на капли и нерегулярные волоконные обрывки;

- зона формуемости (кратность растяжения от 2000 до 2500), характеризующаяся значительной шириной диапазона кратностей растяжения, повышенной устойчивостью процесса аэродинамического формования, регулярностью тонины волокон.

Реализация аэродинамического формования из наполненных прядильных композиций, при высокой кратности растяжения, обеспечивает стабильное формование, а также возможность получения волокнистых материалов, состоящих из волокон минимального диаметра $\left(d_{b}\right)$.

Зоны формуемости прядильных композиций наполненных активированными углями марок СКТ-6 и АГ-5 несколько шире и находятся выше, 


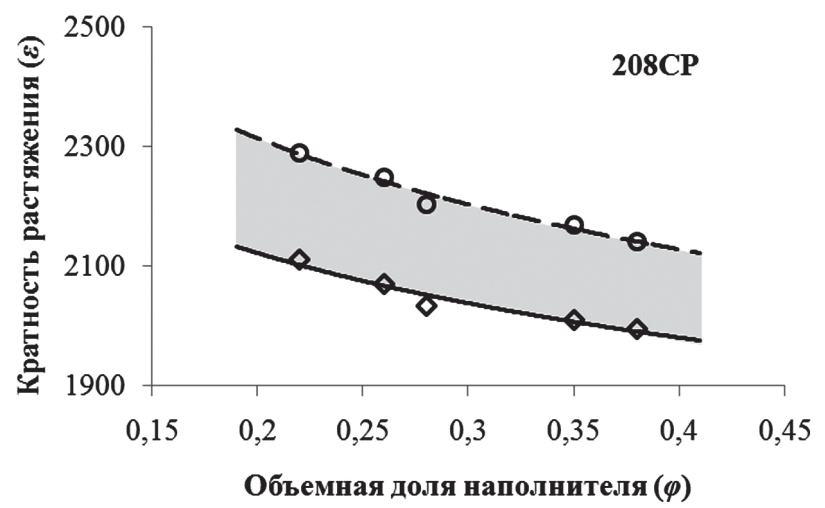

a

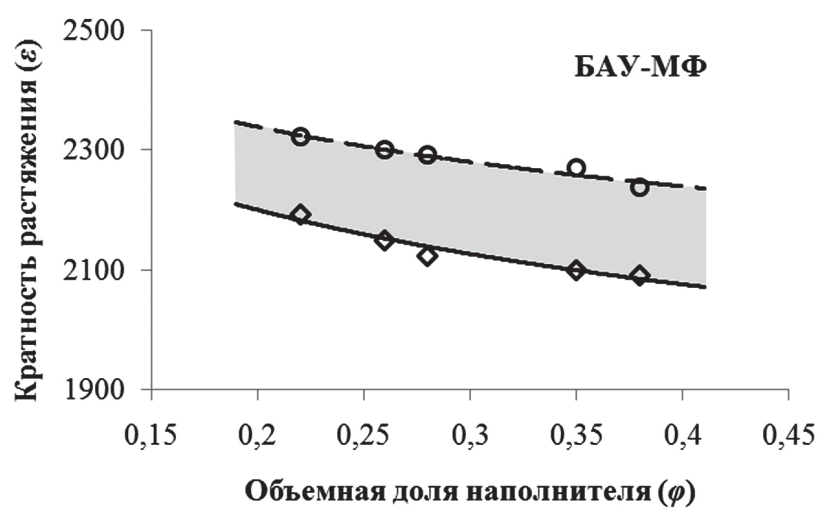

б

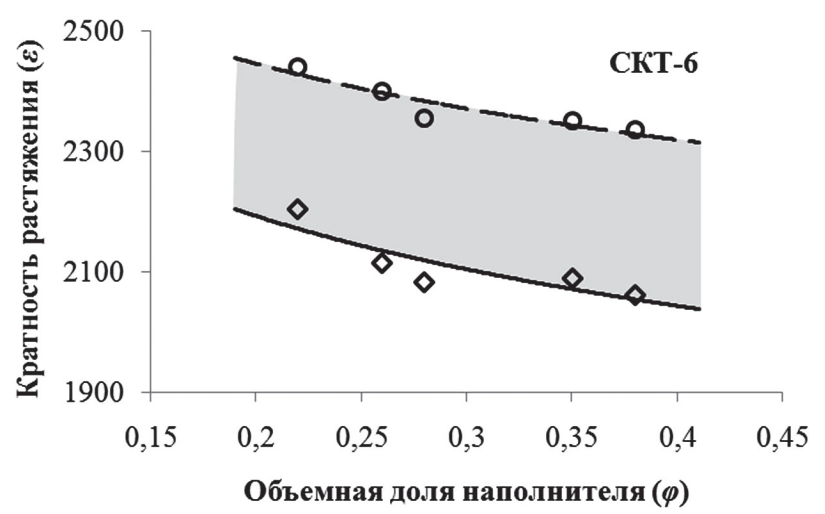

B

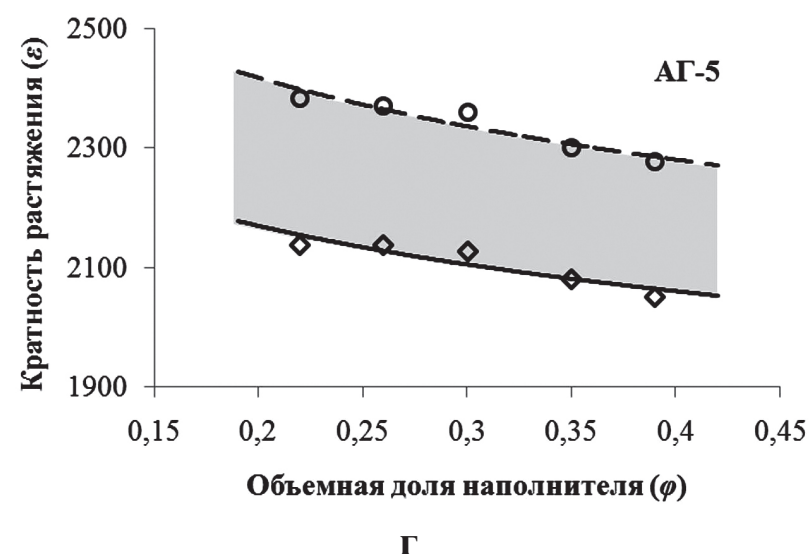

Рис. 3. Зоны формуемости (обозначены темным) прядильных композиций с активированными углями различных марок:

$\mathbf{a}-208 C P$; $\mathbf{\sigma}-Б A У-M \Phi ; \mathbf{B}-C K T-6 ; \mathbf{\Gamma}-A \Gamma-5$ чем у углей 208СР и БАУ-МФ (рис. 3). Поэтому с учетом этой характеристики применение углей марок СКТ-6 и АГ-5 в качестве сорбционно-активных наполнителей позволит проводить более стабильный процесс формования волокнистых наполненных материалов при больших кратностях вытяжки и с меньшим значением конечного диаметра волокна в холсте материала.

У полученных образцов наполненных волокнистых материалов были определены их сорбционные свойства в динамических условиях, в зависимости от относительной влажности газа носителя (воздуха).

Для оценки сорбционных свойств полученных образцов волокнистых наполненных сорбентов применялась методика определения времени защитного действия (ВЗД) по циклогексану с использованием газоанализатора «Колион-1В», служащего индикатором появления циклогексана в отфильтрованном воздухе.

По экспериментально определенным значениям ВЗД рассчитывалась динамическая сорбционная активность $\left(A_{d}\right)$, которая характеризуется максимальным количеством вещества, поглощенного единицей массы активного наполнителя до момента «проскока», то есть появления адсорбтива за образцом материала:

$$
A_{i \ddot{d} \delta}=m / M=\left(\tau_{s} \cdot q \cdot C_{0}\right) /(\rho \cdot S)
$$

где $A_{d}$ - динамическая сорбционная активность материала, мг/г; $m$ - масса адсорбата, мг; $M$ - масса образца материала, г; $\tau_{n p}-$ ВЗД, мин; $q-$ расход газовоздушной смеси, м $3 /$ мин; $C_{0}-$ концентрация адсорбтива (циклогексана) в газовоздушной смеси, мг $/ \mathbf{M}^{3} ; \rho_{s}-$ поверхностная плотность материала, $\Gamma / \mathbf{M}^{2} ; S$ - площадь образца, $\mathbf{M}^{2}$.

Для образцов волокнистых сорбентов, полученных из эквивязких прядильных композиций содержащих различные марки активированных углей, по формуле (3) рассчитывалась динамическая сорбционная активность, при относительной влажности газовоздушной смеси $(W)$ от 0 до $90 \%$. Результаты измерений показаны на рисунке 4.

Из рисунка 4 следует, что благодаря максимальному объему микропор среди рассмотренных активированных углей $\left(0,57-0,60 \mathrm{~cm}^{3} / \Gamma\right)$ и сорбционной площади поверхности (таблица 3) образец волокнистого материала наполненного углем СКТ6 обладает наибольшей динамической сорбционной активностью. Также большим объемом микропор пор $\left(0,45 \mathrm{~cm}^{3} / \Gamma\right)$ и высокими значениями $A_{d}$ обладает уголь $208 \mathrm{CP}$ (рис. 4).

С ростом относительной влажности газовоздушной смеси до $30 \%$ значение $A_{d}$ практически 


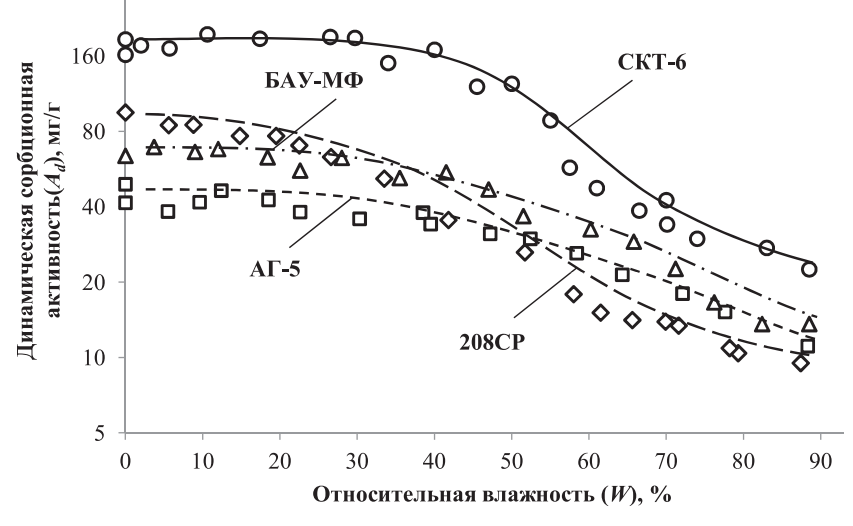

Рис. 4. Графики зависимости динамической сорбционной активности от относительной влажности газовоздушной смеси, для образцов волокнистых сорбентов наполненных углями различных марок

не меняется, однако выше этого порога наблюдается заметное снижение $A_{d}$. Особенно значительно его падение у образца наполненного углем СКТ-6 (при относительной влажности 90 \% динамическая сорбция падает более чем в семь раз). Для других образцов волокнистых сорбентов снижение $A_{d}$ также весьма ощутимо.

При относительной влажности газовоздушной смеси близкой к 100\% образец с активированным углем СКТ-6 остается самым эффективным. Другие марки активированных углей (рис. 4) имеют более низкие значения $A_{d}$ в среде с высокой влажностью.

\section{Влияние диаметра волокон \\ на эксплуатационные свойства материала}

Реализация процесса формования в диапазоне устойчивой зоны формуемости позволяет дополнительно обосновать условия получения наполненных НМ содержащих волокна наименьшего диаметра $\left(d_{b}\right)$, в сочетании с различным количеством $\left(C_{y}\right)$ и дисперсностью наполнителя $\left(D_{y}\right)$.

Диаметр волокна является важнейшим структурным параметром, влияющим количественно на другие показатели структуры НМ и эксплуатационные свойства готового волокнистого сорбционно-активного материала (диаметр пор, физикомеханические свойства, сорбционная активность, воздухо- и паропроницаемость и т.д.) [14].

Чтобы получить волокна минимального диаметра необходимо повысить значение относительной деформации растягиваемой струи. Этого эффекта можно достигнуть за счёт снижения вязко- сти прядильной композиции путём уменьшения её концентрации.

Помимо снижения концентрации прядильной композиции, уменьшающей вязкость, наименьший $d_{6}$ может быть получен за счёт увеличения кратности растяжения полимерной струи в процессе аэродинамического формования, определяемой, как отношение скорости воздушного потока к скорости истечения раствора.

При получении образцов волокнистого наполненного материала методом растворного аэродинамического формования, содержащего активированный уголь марки 208СР в качестве наполнителя, состоящих из волокон минимального диаметра фиксировались и варьировались следующие параметры:

- весовая доля тонкой фракции активированного угля $208 \mathrm{CP}\left(P_{50}\right)-74,3 \%$ масс.;

- количество активированного угля $208 \mathrm{CP}$ в структуре волокнистого материала $\left(C_{y}\right)-50 \%$ мacc.;

- концентрация прядильной композиции $\left(C_{n p}\right)$ от 18,5 до $23,0 \%$ масс.;

- кратность растяжения полимерной струи ( $(\varepsilon)$ от 1775 до 4930.

В процессе исследований из полученных образцов отбирались пробы, для определения диаметра волокон $\left(d_{b}\right)$ и диаметра пор $\left(D_{n}\right)$ с помощью оптического микроскопа Olympus bx-51. На основании полученных данных было установлено, что распределение диаметров элементарных волокон $\left(d_{6}\right)$ в образцах наполненных НМ лучше всего моделируется логарифмическим нормальным законом (величина достоверности аппроксимации составляет $\left.R^{2}=0,89-0,94\right)$ и описывается следующей функцией плотности распределения:

$$
f\left(d_{B}\right)=\frac{1}{d_{B} \sigma \sqrt{2 \pi}} \cdot \exp \left[-\frac{\left(\ln d_{B}-\ln \mu\right)^{2}}{2 \sigma^{2}}\right]
$$

где $d_{6}$ - диаметр элементарных волокон $\left(0<d_{6}<+\infty\right)$, мкм; $\sigma$ и $\mu$ - параметры распределения.

Соответствие распределения $d_{6}$ логарифмическому закону, в волокнистых материалах получаемых аэродинамическим способом, подтверждается рядом исследований по формованию волокнистых материалов, как из расплавов, так и из растворов волокнообразующих полимеров [15, 16, 17]. Установление закона распределения дает возможность проявить тенденции изменения $d_{b}$ и дополнительно определить показатели вариации [9].

Для оценки эффективности применения различных способов регулирования тонины элементарных волокон наполненных НM, за счёт изменения рассмотренных выше параметров аэродина- 
мического формования и основываясь на выбранной статистической модели, вычислялись показатели вариации, значения которых представлены в таблице 6. В качестве показателя однородности использовался коэффициент вариации $(C V)$, характеризующий изменчивость относительно средней величины $\overline{d_{B}}$.

Сравнивая показатели вариации для образцов волокнистого наполненного материала, полученные при различных режимах формования (таблица 6), можно видеть, что изменение кратности вытягивания струи раствора сополимера позволяет обеспечить более устойчивый режим формования и получить более узкое и однородное распределение $d_{в}$ (образцы 5-8), по сравнению с изменением концентрации сополимера в прядильном растворе (образцы 1-4).

При уменышении концентрации прядильной композиции, за счет снижения концентрации ПАН в ДМФ, коэффициент вариации $(C V)$ диаметров элементарных волокон образцов наполненных волок- нистых материалов возрастает с 36,1 до 78,1 \%, для образцов полученных путем увеличения кратности растяжения полимерной струи $C V$ изменяется незначительно и составляет 31,8-36,1 \% (таблица 6).

Такая разница в значениях вариационных показателей говорит о том, что при снижении концентрации полимера процесс аэродинамического формования протекает менее стабильно. Поэтому, более предпочтительным способом получения волокон с минимальным диаметром является увеличение кратности растяжения полимерной струи за счёт уменьшения расхода раствора в процессе аэродинамического формования.

Влияние $d_{8}$ и $D_{n}$ на эксплуатационные свойства образцов волокнистого сорбционно-активного материала, наполненного активированным углем

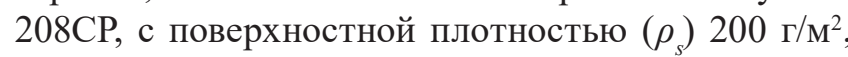
количеством наполнителя $\left(C_{y}\right) 50$ \% масс. и толщиной $(T)$ 1,85 мм, можно увидеть из таблицы 7.

Воздухопроницаемость $(Q)$ определялась в соответствии с ГОСТ - 12088-77 на специальном при-

Таблииа 6

Показатели вариации распределения диаметров элементарных волокон в образцах волокнистых материалов, наполненных активированным углем 208CР

\begin{tabular}{|c|c|c|c|c|c|}
\hline \multirow{2}{*}{$\begin{array}{l}\text { № } \\
\text { п/п }\end{array}$} & \multirow[b]{2}{*}{$C_{n p}, \%$ масс. } & \multirow[b]{2}{*}{$\varepsilon$} & Среднее, мкм & Мода, мкм & $\begin{array}{l}\text { Коэффициент } \\
\text { вариации, \% }\end{array}$ \\
\hline & & & $\bar{d}_{B}=\mu e^{\frac{1}{2} \sigma^{2}}$ & $d_{\text {mod }}=\mu e^{-\sigma^{2}}$ & $C V=\frac{\sqrt{\mu^{2} e^{\sigma^{2}}\left(e^{\sigma^{2}}-1\right)}}{\overline{d_{B}}}$ \\
\hline 1 & 23,0 & 1775 & 48,0 & 39,9 & 36,1 \\
\hline 2 & 20,0 & 1887 & 34,5 & 22,6 & 57,0 \\
\hline 3 & 21,5 & 1931 & 33,5 & 18,1 & 71,2 \\
\hline 4 & 18,5 & 1952 & 22,9 & 11,2 & 78,1 \\
\hline 5 & 21,5 & 1044 & 43,1 & 37,3 & 31,8 \\
\hline 6 & 21,5 & 1290 & 38,5 & 33,4 & 31,8 \\
\hline 7 & 21,5 & 3424 & 30,7 & 25,8 & 35,0 \\
\hline 8 & 21,5 & 4930 & 20,5 & 17,0 & 36,1 \\
\hline
\end{tabular}

Эксплуатационные характеристики образцов волокнистых материалов, наполненных активированным углем $208 C$, с различными структурными параметрами $\left(d_{b}\right.$ и $\left.D_{n}\right)$

\begin{tabular}{|c|c|c|c|c|c|c|}
\hline $\begin{array}{c}\text { № } \\
\text { образца }\end{array}$ & $\begin{array}{l}\overline{d_{B}}, \\
\text { мкM }\end{array}$ & $\begin{array}{l}\overline{D_{n}}, \\
\text { мкм }\end{array}$ & $\begin{array}{c}Q, \\
\operatorname{дM}^{3} /\left(\mathbf{M}^{2} \cdot \text { сек }\right)\end{array}$ & $\begin{array}{l}A_{d}, \\
\mathrm{M \Gamma} / \Gamma\end{array}$ & $\begin{array}{c}\sigma, \\
\text { МПа }\end{array}$ & $\begin{array}{l}\varepsilon, \\
\%\end{array}$ \\
\hline 1 & 43,1 & 245,1 & 257,1 & 73,6 & 1,3 & 2,4 \\
\hline 2 & 38,5 & 211,8 & 137,7 & 99,2 & 2,4 & 2,1 \\
\hline 3 & 33,5 & 185,0 & 84,3 & 102,2 & 4,2 & 3,1 \\
\hline 4 & 30,7 & 170,1 & 56,3 & 111,5 & 4,7 & 3,9 \\
\hline 5 & 20,5 & 112,3 & 37,1 & 106,1 & 5,3 & 4,0 \\
\hline
\end{tabular}


боре ВПТМ-2М для испытания бытовых тканей, тканей технических, военного назначения и для спецодежды, нетканых полотен.

Физико-механические показатели образцов композиционного нетканого материала такие, как разрывная нагрузка $(\sigma)$ и разрывное удлинение $(\varepsilon)$, определяли на приборе для измерения механических свойств нитей «Инстрон» модель 1122 ГОСТ 17318-71.

Снижение $d_{6}$ в холсте наполненного волокнистого материала приводит к уменьшению среднего расстояния между волокнами. Следствием этого является увеличение числа волокон, несущих нагрузку при воздействии приложенного усилия. Одновременно возрастает число склеек в холсте, являющихся дополнительным источником повышения разрывной прочности $(\sigma)$ и разрывного удлинения $(\varepsilon)$ материала (таблица 7) $[14,18]$.

Кроме того, с уменьшением $d_{s}$ значительно возрастает динамическая сорбционная активность $\left(A_{d}\right)$ материала. Это объясняется тем, что диффузия молекул газа к частицам сорбента в волокнах с большим диаметром затруднена. Уменьшение диаметра волокон увеличивает боковую поверхность, открывая доступ к сорбенту и увеличивая скорость внешней диффузии.

Необходимо отметить, что уменьшение $d_{6}$ и $D_{n}$ приводит к резкому падению воздухопроницаемости $(Q)$ нетканого материала (таблица 7), вследствие снижения количества воздуха, проходящего через единицу площади испытываемого образца в единицу времени при постоянном перепаде давления по обе стороны образца волокнистого материала.

Учитывая, что объектом исследования служит волокнистый материал с активированным углём в качестве наполнителя, необходимо установить влияние количества наполнителя в структуре волокнистого материала $\left(C_{y}\right)$, а также дисперсности частиц наполнителя $\left(D_{y}\right)$ на эксплуатационные ха- рактеристики готового волокнистого сорбционноактивного материала.

\section{Влияние количества наполнителя на эксплуатационные свойства материала}

Влияние количества активированного угля $208 \mathrm{CP}$, введенного в полимерную матрицу, на эксплуатационные характеристики готового волокнистого сорбента весьма значительно (таблица 8).

Сорбционную активность образцов волокнистых материалов с различными значениями $C_{y}$ оценивали по потенциалу статической (равновесной) сорбционной емкости $(\alpha)$, который рассчитывался как отношение динамической сорбционной активности $\left(A_{d}\right)$ к статической сорбционной емкости $\left(A_{s}\right)$ материала по циклогексану [18].

Важная особенность волокнистых наполненных сорбентов состоит в том то, что с увеличением содержания наполнителя возрастает $\alpha$, при постоянных $d_{s}$ и $D_{y}$. Это может быть связано с тем, что лимитирующей стадией в процессе сорбции адсорбтива волокнистым материалом является диффузия адсорбтива через полимер к частицам активного наполнителя. Чем выше степень наполнения волокнистой структуры холста, при равных $d$ и $D_{y}$, тем меньше время диффузии адсорбтива к частицам наполнителя, приводящее к увеличению $\alpha$.

Увеличение $C_{y}$ приводит к росту дефектности волокон, то есть, при деформировании материала частицы наполнителя являются источником дефектов и трещин в полимерной матрице, что в итоге значительно уменьшает $\sigma$ (таблица 8 ).

\section{Влияние дисперсности наполнителя на эксплуатационные свойства материала}

Для определения влияния дисперсности наполнителей на эксплуатационные характеристики готового волокнистого сорбционно-активного материала были подготовлены образцы активиро-

\section{Таблица 8}

Эксплуатационные характеристики образцов волокнистых материалов, наполненных активированным углем 208CР, с различным количеством наполнителя в структуре материала $\left(C_{y}\right)$

\begin{tabular}{|c|c|c|c|c|c|}
\hline $\begin{array}{c}\text { № } \\
\text { образца }\end{array}$ & $\begin{array}{c}C_{y}, \\
\% \text { мacc. }\end{array}$ & $\begin{array}{c}A_{s}, \\
\mathrm{M \Gamma} / \Gamma\end{array}$ & $\begin{array}{c}A_{d}, \\
\mathbf{M \Gamma} / \Gamma\end{array}$ & $\alpha$ & $\begin{array}{c}\sigma, \\
\text { МПа }\end{array}$ \\
\hline 1 & 16,7 & 52,6 & 24,3 & 0,46 & 6,2 \\
\hline 2 & 33,3 & 104,9 & 56,9 & 0,54 & 5,3 \\
\hline 3 & 50,0 & 157,5 & 103,2 & 0,66 & 3,3 \\
\hline 4 & 60,0 & 189,0 & 132,5 & 0,70 & 2,3 \\
\hline 5 & 70,0 & 220,5 & 161,2 & 0,73 & 1,5 \\
\hline
\end{tabular}


ванного угля 208СР с различным содержание тонкой фракции (размер частиц меньше 50 мкм), для чего образцы наполнителей измельчались на ультрацентробежной мельнице ZM 200 с 2-х шаговой системой ротор-сито и максимальной скоростью вращения ротора 18000 об/мин, с последующим фракционированием на вибрационном сите Fritsch Analysette.

Размер частиц наполнителей после измельчения и фракционирования определялся с помощью метода лазерной дифракции на анализаторе «Микросайзер 201А», предназначенного для быстрого измерения распределения частиц по размерам в суспензиях.

Результаты анализа дисперсного состава полученных фракций представлены в виде графиков распределения диаметров частиц сорбционно-активного наполнителя (рис. 5). Для статистического описания и последующего анализа распределений по размерам частиц измельченных материалов существуют разные формулы. Распределение частиц наполнителя по размерам с различными весовыми долями тонкой фракции $\left(P_{50}\right)$ может быть с достаточной точностью описано логарифмически нормальным распределением (ЛНР), которое получается, если в нормальную Гауссову функцию подставить в качестве аргумента не диаметр частиц, а логарифм диаметра. Справедливость логарифмически нормального закона для всех случаев, когда мы имеем дело с частицами вещества, полученными механическим измельчением в течение длительного времени, теоретически доказана Колмогоровым. Применимость этого закона для многих видов пылей и порошкообразных материалов подтверждается рядом экспериментальных исследований $[19,20]$.

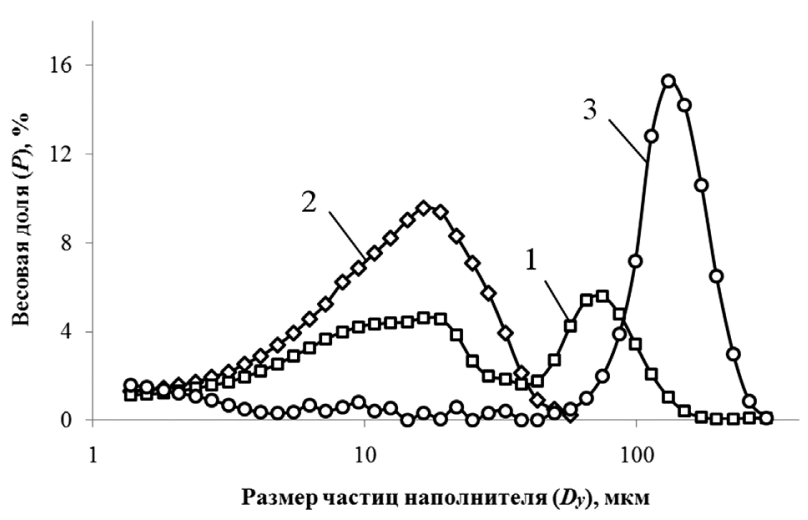

Рис. 5. Распределение размеров частиц активированного угля 208СР с различными весовыми долями тонкой фракции $\left(P_{50}\right)$ : $1-74,3 \% ; 2-99,8 \% ; 3-20,4 \%$
Функция ЛНР массы наполнителя по диаметрам частиц $F\left(D_{y}\right)$ имеет следующий вид:

$F\left(D_{y}\right)=\frac{100}{\lg \sigma \sqrt{2 \pi}} \int_{-\infty}^{\lg D_{y}} \exp \left[-\frac{\left(\lg D_{y}-\lg \mu\right)^{2}}{2 \lg ^{2} \sigma}\right] d \lg D_{y}$

где $D_{y}$ - диаметр частиц наполнителя $\left(0<D_{y}<\infty\right)$, мкм; $\sigma$ и $\mu$ - параметры распределения.

Дифференцирование функции распределения $F\left(D_{y}\right)$ по $D_{y}$ дает функцию плотности ЛНР $f\left(D_{y}\right)$ :

$f\left(D_{y}\right)=\frac{100 \lg e}{D_{y} \lg \sigma \sqrt{2 \pi}} \cdot \exp \left[-\frac{\left(\lg D_{y}-\lg \mu\right)^{2}}{2 \lg ^{2} \sigma}\right]$

Чтобы оценить эффективность предложенного способа получения сорбционно-активного наполнителя различного гранулометрического состава из кривых распределения частиц наполнителя по размерам вычислялись следующие показатели вариации:

$$
\begin{aligned}
& D_{\text {mod }}=e^{\mu-\sigma^{2}} \\
& \bar{D}_{y}=e^{\mu+\sigma^{2} / 2}
\end{aligned}
$$

где $D_{\text {mod }}$ - мода распределения частиц наполнителя (значение встречающееся наиболее часто), мкм; $\bar{D}_{y}$ - средний диаметр частиц наполнителя, мкм.

Методом растворного аэродинамического формования были получены образцы волокнистых сорбентов, содержащие активированный уголь 208СР с различной дисперсностью. Количество наполнителя при этом составляло $(C) 50$ \% масс., концентрация прядильной композиции $\left(C_{n p}\right) 21,5 \%$ масс., кратность растяжения полимерной струи $(\varepsilon)$ 1900 - 2100. Результаты расчетов показателей вариации по формулам (6) - (8), а также эксплуатационные характеристики полученных образцов волокнистого сорбента, представлены в таблице 9, где $P_{50}$ - весовая доля тонкой фракции (размер частиц меньше 50 мкм), $A_{d}$ - динамическая сорбционная активность, $\sigma$ и $\varepsilon$ - разрывная прочность и разрывное удлинение соответственно. Из данных представленных в указанной таблице очевидна значительная разница в величине указанных свойств волокнистого сорбента с наполнителем разной степени дисперсности.

Образцы волокнистых сорбентов содержащие 99,8 \% мелкодисперсного угля в качестве наполнителя обладают значительно более высокой $A_{d}$ по сравнению с образцами содержащими 74,3 и $20,4 \%$. Одновременно образцы с крупнодисперсным наполнителем имеют значительно более 
Эксплуатационные характеристики и показатели вариации образцов волокнистого сорбента, с различной дисперсностью наполнителя $\left(D_{y}\right)$

\begin{tabular}{|c|c|c|c|c|c|c|}
\hline $\begin{array}{c}\text { № } \\
\text { образца }\end{array}$ & $\boldsymbol{P}_{50}$ & $\begin{array}{l}D_{\text {mod }} \text {, } \\
\text { MKM }\end{array}$ & $\begin{array}{l}\bar{D}_{y}, \\
\text { мкм }\end{array}$ & $\begin{array}{c}A_{d}, \\
\mathrm{M \Gamma} / \Gamma\end{array}$ & $\begin{array}{c}\sigma, \\
\text { МПа }\end{array}$ & $\begin{array}{l}\varepsilon \\
\%\end{array}$ \\
\hline 1 & 74,3 & $\begin{array}{l}20,7 \\
55,3\end{array}$ & $\begin{array}{l}29,3 \\
94,5\end{array}$ & 95,1 & 4,5 & 3,8 \\
\hline 2 & 99,8 & 9,9 & 11,3 & 111,4 & 3,4 & 2,7 \\
\hline 3 & 20,4 & 65,4 & 71,6 & 87,9 & 5,0 & 8,2 \\
\hline
\end{tabular}

высокие физико-механические свойства по сравнению с образцами содержащими мелкодисперсный наполнитель.

В первом случае повышение значения $A_{d}$ определяется тем, что уменьшение размера частиц активированного угля очень сильно влияет на скорость адсорбции. Порошкообразный активированный уголь с размером частиц $\left(D_{y}\right)$ около 10-20 мкм достигает $90 \%$ от равновесной сорбционной емкости $\left(A_{s}\right)$ менее чем за 19 мин, в то время как для гранулированного угля потребуется несколько дней. Во втором случае поверхностное расположение крупнодисперсного наполнителя гарантирует минимальное разрушении адгезионных связей с наполнителем в процессе деформации волокнистой матрицы, обеспечивающее рост физико-механических свойств [20].

\section{Регрессионный анализ полученных результатов}

Для анализа взаимосвязи между рассмотренными структурными параметрами, такими, как диаметр волокон в холсте $\left(d_{6}\right)$, концентрация наполнителя $\left(C_{y}\right)$ и его дисперсность $\left(D_{y}\right)$, а также основными эксплуатационными характеристиками $\left(A_{d}\right.$ и $\left.\sigma\right)$ полученных образцов наполненных волокнистых сорбентов, был применен метод множественной регрессии. Общее его назначение состояло в определении количественных соотношений между несколькими независимыми переменными $\left(d_{\sigma}, C_{y}\right.$ и $\left.D_{y}\right)$ и зависимой переменной $\left(A_{d}\right.$ или $\left.\sigma\right)$.

Методом множественного нелинейного регрессионного анализа определены уравнения, свя- зывающие указанные параметры с перечисленными выше эксплуатационными характеристиками волокнистых сорбентов:

$A_{d}=2,68-0,02 d_{B}^{2}+2,12 C_{y}-0,26 D_{y}$

$\sigma=8,55-2,06 \cdot 10^{-3} d_{B}^{2}-0,09 C_{y}+0,02 D_{y}$

Совокупное влияние всех независимых переменных $\left(d_{\sigma^{\prime}} C_{y}\right.$ и $\left.D_{y}\right)$ на зависимые переменные $\left(A_{d}\right.$ или $\sigma$ ) в модели множественной нелинейной регрессии оценивалось с помощью коэффициента детерминации $R^{2}$ и множественного коэффициента корреляции $R$, анализ которых показывает, что модель объясняет большую часть изменчивости соответствующих переменных. Связи между переменными по шкале Чеддока могут быть оценены как весьма высокие $(0,9<R<1,0)$. Коэффициенты детерминации и корреляции приведены в таблице 10.

Количественные вклады независимых переменных $\left(d_{b}, C_{y}\right.$ и $\left.D_{y}\right)$ в изменение эксплуатационных свойств волокнистых сорбентов оценивались с помощью $\beta$-коэффициентов (стандартизированные коэффициенты регрессии), которые показывают на какую часть величины среднего квадратического отклонения изменится зависимая переменная с изменением соответствующей независимой переменной на величину своего среднеквадратического отклонения при фиксированном на постоянном уровне значении остальных независимых переменных. Чем больше $\beta$-коэффициент, тем сильнее влияние независимой переменной. Отрицательные значение $\beta$-коэффициентов говорят об обратнопропорциональной зависимости.

Таблицุа 10

Результаты множественного нелинейного регрессионного анализа исходных данных

\begin{tabular}{|c|c|c|c|c|c|}
\hline \multirow{2}{*}{$\begin{array}{c}\text { Зависимые } \\
\text { переменные }\end{array}$} & \multicolumn{3}{|c|}{ Стандартизированные коэффициенты регрессии } & \multirow{2}{*}{$R$} & \multirow{2}{*}{$R^{2}$} \\
\hline & $\beta d_{B}$ & $\beta C_{y}$ & $\beta D y$ & & \\
\hline$A_{d}$ & $-0,32$ & 0,93 & $-0,17$ & 0,97 & 0,95 \\
\hline$\sigma$ & $-0,59$ & $-0,68$ & 0,24 & 0,96 & 0,92 \\
\hline
\end{tabular}


Из результатов регрессионного анализа (таблица 10) следует, что наибольшее влияние на $A_{d}$ и $\sigma$ оказывает количество наполнителя введенного в полимерную матрицу $(C)$, причем с увеличением $C_{y}$ динамическая сорбционная активность $\left(A_{d}\right)$ значительно возрастает, а прочность $(\sigma)$ резко падает (таблица 8).

Вторым по значимости структурным параметром, определяющим эксплуатационные свойства волокнистых сорбентов является $d_{g}$, с уменьшением которого $A_{d}$ и $\sigma$ увеличиваются (таблица 7). Кроме того, весомое влияние на активность наполнителя, а следовательно $A_{d}$ и $\sigma$, оказывает размер частиц наполнителя $\left(D_{y}\right)$. С увеличением $D_{y}$ динамическая сорбционная активность $\left(A_{d}\right)$ снижается, а прочность $(\sigma)$ возрастает (таблица 9).

Анализ преимуществ и недостатков рассмотренных в работе активированных углей различных марок (таблица 11), а также регулирование структурных параметров $\left(d_{g^{\prime}} D_{n}, C_{y}\right.$ и $\left.D_{y}\right)$ волокнистых наполненных материалов, обеспечивает изменение эксплуатационных свойств в широком диапазоне, что позволяет формировать материал со свойствами оптимально подходящими для применения в готовых изделиях в различных областях промышленности.

Из данных в таблице 11 следует, что активированный уголь СКТ-6 целесообразно применять в изделиях специального назначения (СИЗОД и СИЗК), эксплуатируемых в среде с повышенной влажностью.
Защитную одежду с включением активированного угля марки $208 \mathrm{CP}$ удобно изготавливать на базе разработанных нетканых композиционных материалов ВСАМ и ВУМ в изделиях общего назначения.

В настоящее время в АО «ВНИИСВ» выпускаются такие марки наполненных сорбционноактивных волокнистых материалов, как ВСАМ и ВУМ, которые получают методом аэродинамического формования растворов полиакрилонитрила (материал ВСАМ), либо полиуретана (материал ВУМ), содержащих в качестве наполнителя 50$60 \%$ масс. мелкодисперсного активированного угля. Основные области применения материалов ВСАМ и ВУМ - это производство СИЗОД и СИЗК, системы воздухоочистки, поглотители запаха, химическая промышленность.

\section{Многослойные (гибридные) волокнистые сорбенты}

Помимо рассмотренных выше групп волокнистых сорбционно-активных полимерных материалов широкое распространение получили многослойные (композиционные) волокнистые сорбенты, состоящие из двух и более слоев различной текстильной формы. В качестве слоев могут использоваться, как физически и химически модифицированные волокнистые материалы (АУВ или ионообменные волокна), так и композитно модифицированные наполненные волокнистые материалы.

Таблиияа 11

Преимущества и недостатки различных марок активированных углей для формования наполненных волокнистых сорбционно-активных материалов

\begin{tabular}{|c|c|c|}
\hline Марка угля & Преимущества & Недостатки \\
\hline $208 \mathrm{CP}$ & $\begin{array}{l}\text { • высокая сорбционная активность при низкой } \\
\text { влажности } \\
\text { • стабильная суспензия } \\
\text { • выпускается в удобной форме (порошок) }\end{array}$ & $\begin{array}{l}\text { • очень низкая сорбционная активность при } \\
\text { высокой влажности } \\
\text { • высокая вязкость прядильной композиции } \\
\text { • уголь импортного производства } \\
\text { • высокая стоимость } \\
\text { • узкая зона формуемости }\end{array}$ \\
\hline БАУ-МФ & • невысокая стоимость & $\begin{array}{l}\text { • суспензия очень нестабильна } \\
\text { • высокая вязкость прядильной композиции } \\
\text { • низкая сорбционная активность } \\
\text { • узкая зона формуемости }\end{array}$ \\
\hline СКТ-6 & $\begin{array}{l}\text { • высокая сорбционная активность при низкой } \\
\text { и большой влажности } \\
\text { • стабильная суспензия } \\
\text { • широкая зона формуемости }\end{array}$ & • высокая стоимость \\
\hline $\mathrm{A} \Gamma-5$ & $\begin{array}{l}\text { • низкая вязкость прядильной композиции } \\
\text { • невысокая стоимость } \\
\text { • широкая зона формуемости }\end{array}$ & $\begin{array}{l}\text { • суспензия нестабильна } \\
\text { • невысокая сорбционная активность }\end{array}$ \\
\hline
\end{tabular}


Целью выпуска таких материалов является очистка воздуха и воды от сложной композиции из токсических компонентов кислой, основной и органической природы. По требованию потребителей может быть сформирована любая комбинация материалов в зависимости от состава загрязняющих веществ.

Технология производства многослойных волокнистых сорбентов достаточно проста и заключается в нанесении связующего на одну или несколько сторон скрепляемых поверхностей и дальнейшего соединения волокнистых материалов с применением термического воздействия и усилия сжатия, создаваемых на специализированном оборудовании [21].

В АО «ВНИИСВ» в настоящее время разрабатывается технология аэродинамического растворного формования в одну стадию комбинированного наполненного волокнистого сорбента, содержащего различные наполнители с определенной последовательностью и чередованием слоев, что должно значительно упростить и удешевить технологию [22, 23].

В сравнении с технологией дублирования данный способ позволяет на одном и том же оборудовании получать волокна с высоким содержанием наполнителя без использования связующих веществ и формировать готовые холсты наполненного волокнистого сорбента, с целью последующего его применения при производстве средств индивидуальной защиты, с требуемыми эксплуатационными свойствами [23].

В качестве сорбционно-активных наполнителей были выбраны наиболее эффективные неор- ганические сорбенты и химические поглотители зарубежного и отечественного производства, для комплексного удаления АХОВ классов Е и К (кислые газы и аммиак). Основные характеристики наполнителей, полученные авторами в процессе исследования, представлены в таблице 12.

Таким образом, наибольшей сорбционной ёмкостью по аммиаку обладают волокнистые материалы наполненные силикагелем КСМГ и купрамитом, по диоксиду серы - анионитом АН-31 и химическим поглотителем ХП-И. Наполнитель цеолит $\mathrm{NaX}$ можно использовать как универсальный неорганический сорбент (таблица 12).

Необходимо отметить, что получение волокнистого сорбента с импортным наполнителем PURAFIL PSP-BX невозможно, так как данный химический поглотитель импрегнирован специальным химическим реагентом, который вызывает структурирование прядильной композиции непригодной для формования волокнистого материала из растворов аэродинамическим способом.

К многослойным волокнистым сорбентам можно отнести и так называемые «сэндвич» материалы, которые, как правило, представляют собой слой гранулированного сорбента закрепленного с помощью специального связующего между слоями подстилающего и покрывного волокнистого материала. В качестве покрывного слоя часто применяется специальный фильтрующий материал, состоящий из ультратонких волокон, либо слой огнестойкого и водоотталкивающего покрытия.

Основными производителями многослойных волокнистых сорбентов, выпускаемых за рубежом,

Таблица 12

Характеристики наиболее эффективных марок неорганических сорбентов и химических поглотителей

\begin{tabular}{|c|c|c|c|}
\hline \multirow{2}{*}{$\begin{array}{c}\text { Марка } \\
\text { сорбента }\end{array}$} & \multirow[t]{2}{*}{ Назначение } & \multicolumn{2}{|c|}{$\begin{array}{l}\text { Сорбционная } \\
\text { ёмкость, мг/г }\end{array}$} \\
\hline & & $\mathrm{NH}_{3}$ & $\mathrm{SO}_{2}$ \\
\hline Цеолит $\mathrm{NaX}$ & Очистка газовых потоков от воды, $\mathrm{NH}_{3}, \mathrm{H}_{2} \mathrm{~S}, \mathrm{CO}_{2}$ и других газов & 130 & 71 \\
\hline $\begin{array}{l}\text { Силикагель } \\
\text { КСМГ }\end{array}$ & Осушка и очистка воздуха и других газов (паров) & 341 & 19 \\
\hline Купрамит & Снаряжение противогазов. Защита от $\mathrm{NH}_{3}, \mathrm{H}_{2} \mathrm{~S}$ и других газов & 288 & - \\
\hline PCBAM-BXESD & $\begin{array}{l}\text { Очистка газовых потоков от } \mathrm{NH}_{3} \text {, метиламина, триэтиламина и } \\
\text { других газов }\end{array}$ & 185 & - \\
\hline $\begin{array}{l}\text { Химический } \\
\text { поглотитель } \\
\text { ХП-И }\end{array}$ & $\begin{array}{l}\text { Используется в СИЗОД при работе в атмосфере содержащей газы } \\
\text { кислотного характера, например } \mathrm{SO}_{2}, \mathrm{HC}, \mathrm{NO}_{2}\end{array}$ & - & 90 \\
\hline Анионит АН-31 & Применяют в системах очистки от кислых газов & - & 180 \\
\hline PURAFIL PSP-BX & Сорбент для удаления $\mathrm{H}_{2} \mathrm{~S}, \mathrm{SO}_{2}, \mathrm{NO}_{2}$ & - & 89 \\
\hline
\end{tabular}


являются - Hollingsworth \& Vose Company (США), Ahlstrom (Финляндия), Blücher (Германия), Airdot Environmental Technologies (Китай). В России многослойные волокнистые сорбенты выпускает АО «ВНИИСВ» под марками «ФЗМ» и «КФСМ».

Несмотря на достаточно высокую защитную способность зарубежных углесодержащих многослойных волокнистых сорбентов, перспективным считается постепенный переход к выпуску СИЗК из многослойных нетканых полимерных материалов с селективно проницаемыми мембранами $(\mathrm{CПM)} \mathrm{без} \mathrm{использования} \mathrm{активированных} \mathrm{углей.}$ Эти СИЗК, являясь легкими и компактными, способны обеспечить защиту от поражающих факторов ядерного, химического и биологического оружия при высоких гигиенических и эргономических показателях [24].

К основным производителям многослойных волокнистых сорбентов с СПМ можно отнести компанию DuPont (США) выпускающую мембранный материал под маркой Тусhem, представляющий собой нетканый материал в сочетании с полимерным покрытием, либо с высокоэффективной барьерной пленкой, а также компанию Gore (США) производящую аналогичный материал под маркой Chempak.

Стоит отметить, что опасность влияния загрязненного атмосферного воздуха и воды на здоровье населения обусловлена разнообразием загрязнений. Считается, что на человека, проживающего в промышленном районе, или работающего на промышленном предприятии, потенциально может воздействовать несколько сотен тысяч химических веществ. Как правило, на конкретном производстве реально присутствует ограниченное число химических веществ в относительно высоких концентрациях. Однако, комбинированное действие атмосферных загрязнителей может привести к усилению вызываемых ими токсических эффектов.

Для предотвращения комбинированного действия различных химических загрязнителей все больше будут востребованы универсальные материалы и изделия, выполняющие одновременно несколько защитных функций, в числе которых защита от аэрозолей и паров органических АХОВ ингаляционного действия, а также защита от аэрозолей и паров токсичных химикатов. Потребление подобных высокоэффективных материалов комбинированного действия будет постоянно возрастать, особенно с учетом прогнозов роста природных катаклизмов.

Именно по этой причине наиболее перспективно выглядят материалы группы многослойных (гибридных) волокнистых сорбентов, сформирован- ные благодаря последовательной укладке различных слоев в единый волокнистый холст. Указанные многослойные сорбенты в значительной степени отвечают современным требованиям, предъявляемым к качеству материалов, используемых для разработки защитной и специальной одежды, а также респираторов нового поколения.

Важным является тот факт, что в России существует целый ряд предприятий (АО «ВНИИСВ», АО «КазХимНИИ», ООО «Лирсот», ОАО «ЭНПО «Неорганика», ООО «Респираторный комплекс» и др.) производящих высокотехнологичные волокнистые полимерные сорбенты и изделия из них, по свойствам находящиеся на уровне, а в ряде случаев и превосходящие лучшие зарубежные аналоги. Специализированными институтами проводятся научно-исследовательские работы по совершенствованию имеющихся и разработке новых инновационных технологий получения волокнистых сорбентов. Эти материалы могут составить достойную конкуренцию волокнистым сорбентам производимым ведущими зарубежными фирмами и помочь не допустить зависимости отечественной системы защиты войск, предприятий химической и нефтехимической промышленности, а также населения от закупок зарубежной продукции.

\section{Литература}

1. Перепелкин K.E. Российский химический журнал. 2002. T. XLVI. № 1. C. 31-48.

2. Мелешко А.И., Половников С.П. Углерод. Углеродные волокна. Углеродные композиты. - М.: Сайнспресс, 2007. - 192 c.

3. Chen J. Activated Carbon Fiber and Textiles. The Textile Institute: Elsevier, 2016. p. 362.

4. Luqman M. Ion Exchange Technology I: Theory and Materials. Springer Science+Business Media, 2012. p. 550 .

5. Эннан А.А., Байденко В.И. и др. Энерготехнологии и ресурсосбережение. 2011. № 1. С. 50-56.

6. Радкевич В.З., Хаминеи С.Г. и др. Научно-практический семинар «Волокна и волокнистые материалы специального назначения. Исследования и разработки». Минск. 2015. С. 47-49.

7. Das D. Composite Nonwoven Materials: Structure, Properties and Applications. The Textile Institute: Elsevier, 2014. p. 252.

8. Генис А.В, Усов В.В., Идиатулов Р.К. Патент РФ №62931. Установка для получения сорбционнофильтрующих нетканых материалов из растворов полимеров аэродинамическим формованием. 22.08.2006.

9. Кузнецов А.В., Генис А.В. и др. Химические волокна. 2015. №1. C. 34-39.

10. Новый справочник химика и технолога. Сырье и продукты промышленности органических 
и неорганических веществ. Ч. 1. - С.-Пб.: АНО НПО «Профессионал», 2002. - 988 с.

11. Липатов Ю.С. Физико-химические основы наполнения полимеров. - М.: Химия, 1991. - 260 с.

12. Ходаков Г.С. Российский химический журнал. 2003. T. XLVII. № 2. C. 33-44.

13. Нильсен Л. Механические свойства полимеров и полимерных композиций. - Пер. с англ. канд. техн. наук Бабаевского П.Г. - М.: Химия, 1978. - 312 с. (Nielsen L., Mechanical properties of polymers and composites, NewYork, MarcelDekker, 1974).

14. Кузнецов А.В., Генис А.В. и др. Химические волокна. 2015. № 6. C. 68-74.

15. Ellison C., Phatak A. et al. Polymer. 2007. V. 48. P. 3306-3316.

16. Zhuang X., Jia K., Cheng B., Guan K. Journal of Engineered Fibers and Fabrics. 2013. Vol. 8. P. 88-93.

17. Hassan M., Yeom B. et al. Journal of Membrane Science. 2013. V. 427. P. 336-344.
18. Генис А.В., Кузнецьов А.В. Пластические массы. 2016. № 11-12. C. 27-32.

19. Коузов П.А. Основы анализа дисперсного состава. Л.: Химия, 1987.264 с.

20. Кузнецов А.В., Генис А.В. Вопросы оборонной техники. Серия 15. Композиционные неметаллические материалы в машиностроении. 2016. №2. С. 116-123.

21. Генис А.В., Кузнецов А.В. и др. Пластические массы. 2016. № 7-8. C. 56-61.

22. Генис А.В., Кузнециов А.В. и др. Патент РФ №2607585. Многослойный фильтровально-сорбционный нетканый материал. 16.11.2015.

23. Генис А.В., Идиатулов Р.К. и др. Патент РФ №2668446. Установка для получения сорбционнофильтрующих нетканых материалов с улучшенными свойствами из растворов полимеров методом аэродинамического формования. 01.10.2018.

24. Борисов А.А. Зарубежное военное обозрение. 2016. № 9. C. 52-55. 